\title{
Distribution and predictors associated with the use of breast cancer screening services among women in 14 low-resource countries
}

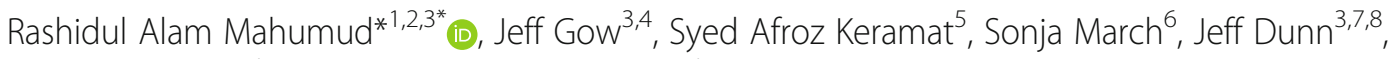 \\ Khorshed Alam ${ }^{3+}$ and Andre M. N. Renzaho ${ }^{1,2+}$
}

\begin{abstract}
Background: Breast cancer is one of the leading public health problem globally, especially in low-resource countries (LRCS). Breast cancer screening (BCS) services are an effective strategy for early determining of breast cancer. Hence, it is imperative to understand the utilisation of BCS services and their correlated predictors in LRCs. This study aims to determine the distribution of predictors that significantly influence the utilisation of BCS services among women in LRCs.

Methods: The present study used data on 140,974 women aged 40 years or over from 14 LRCs. The data came from country Demographic and Health Surveys (DHS) between 2008 and 2016. Multivariate logistic regression analysis was employed to investigate the significant predictors that influence the use of BCS services.

Results: The utilisation of BCS services was 15.41\%, varying from $81.10 \%$ (95\% Cl: $76.85-84.73 \%$ ) in one European country, to $18.61 \%$ (95\% Cl: 18.16 to 19.06\%) in Asian countries, $14.30 \%$ (95\% Cl: 13.67-14.96\%) in American countries, and $14.29 \%$ (95\% Cl: 13.87-14.74\%). Factors that were significantly associated to increase the use of BCS services include a higher level of education $(\mathrm{OR}=2.48)$, advanced age at first birth ( $>25$ years) $(\mathrm{OR}=1.65)$, femaleheaded households $(O R=1.65)$, access to mass media communication $(O R=1.84)$, health insurance coverage $(O R=$ 1.09), urban residence $(O R=1.20)$ and highest socio-economic status $(O R=2.01)$. However, obese women shown a significantly $11 \%(\mathrm{OR}=0.89)$ lower use of BSC services compared to health weight women.
\end{abstract}

(Continued on next page)

\footnotetext{
* Correspondence: rashed.mahumud@gmail.com;

rashed.mahumud@usq.edu.au

${ }^{\dagger}$ Khorshed Alam and Andre M. N. Renzaho contributed equally to this work.

${ }^{1}$ School of Social Sciences, Western Sydney University, Penrith, New South

Wales 2751, Australia

${ }^{2}$ Translational Health Research Institute (THRI), Western Sydney University,

Sydney, New South Wales, Australia

Full list of author information is available at the end of the article
}

(c) The Author(s). 2020 Open Access This article is licensed under a Creative Commons Attribution 4.0 International License, which permits use, sharing, adaptation, distribution and reproduction in any medium or format, as long as you give appropriate credit to the original author(s) and the source, provide a link to the Creative Commons licence, and indicate if changes were made. The images or other third party material in this article are included in the article's Creative Commons licence, unless indicated otherwise in a credit line to the material. If material is not included in the article's Creative Commons licence and your intended use is not permitted by statutory regulation or exceeds the permitted use, you will need to obtain permission directly from the copyright holder. To view a copy of this licence, visit http://creativecommons.org/licenses/by/4.0/ The Creative Commons Public Domain Dedication waiver (http://creativecommons.org/publicdomain/zero/1.0/) applies to the data made available in this article, unless otherwise stated in a credit line to the data. 


\begin{abstract}
(Continued from previous page)
Conclusion: The utilisation of BCS services is low in many LRCs. The findings of this study will assist policymakers in identifying the factors that influence the use of BCS services. To increase the national BCS rate, more attention should be essential to under-represented clusters; in particular women who have a poor socioeconomic clusters, live in a rural community, have limited access to mass media communication, and are have a low level educational background. These factors highlight the necessity for a new country-specific emphasis of promotional campaigns, health education, and policy targeting these underrepresented groups in LRCs.
\end{abstract}

Keywords: Breast cancer screening services, Low-resource countries, Reproductive women, Determinants

\section{Background}

Breast cancer $(\mathrm{BC})$ is one of the public health problem worldwide and the second leading cause of overall death due to cancer [1]. In 2018, nearly 2.1 million women experienced $\mathrm{BC}$ and 627,000 women died from it (i.e., accounting for fiften percent of all cancer deaths) [2]. The rate of incidence, mortality and survival of $\mathrm{BC}$ vary across countries $[3,4]$. The incidence rate of $\mathrm{BC}$ is increasing in low-resource countries (LRCs) due to demographic transition, changing disease patterns, unhealthy lifestyles, and behaviors that lead to a high risk of $\mathrm{BC}$ incidence [5-9]. Although the incidence rate of $\mathrm{BC}$ in developed countries is 89 per 100,000 women, it is below 40 in LRCs [10]. However, in recent times, this low incidence rate in LRCs have been increasing at a faster rate compared to developed countries [11]. The mortality rate of $\mathrm{BC}$ is also increasing in this setting; for instance, about $60 \%$ of women die due to BC in LRCs [10]. The five-year survival rates of $\mathrm{BC}$ varies to a great extent globally, ranging from $80 \%$ (in developed countries) to less than $40 \%$ (in developing countries) [12]. Therefore, the burden of $\mathrm{BC}$ is particularly underdetermined in LRCs.

Breast cancer disproportionately affects more among reproductive women (aged 15-49 years) in LRCs (23\% of new cases) than developed countries (10\% of new cases) [13]. The recommended starting age for routine BCS varies widely as well due to lack of government recommendations [14-19]. However, a few proportion (2.2\%) of aged women (i.e., aged 40-69 years) had utilised screening services in LRCs [20].

In LRCs, some predictors that could decline the efficacy of BCS services include a younger women with the lower incidence of $\mathrm{BC}$, poor health status, and a prevalence of biologically destructive sub-types for which patient outcomes are associated with lower utilisation of screening services [13]. Conversely, BCS could have a greater impact in LRCs if it promotes BC awareness, knowledge, percention, and early screning of symptomatic disease. For instance, there may be greater effects than would be anticipated in developed settings, where strong health systems and higher levels of awareness reduce the opptornuty of BCS primarly to the detection of asymptomatic disease. Also, LRCs recurrently lack the requisite skeletal structure to corroborate high-quality mammography and afterwards healthcare services [14], which in commit may be restricted by a lack of resources (i.e., $x$-ray films, and mammography) $[15,16]$. In LRCs, most monographs are provided through private hospitals, making it unaffordable $[17,18]$. In this context, evidence is required to lead large-scale BCS in LRCs considering socio-economic status and cultural affiliations, as effects on $\mathrm{BC}$-specific death rates remain unclear. Inadequate cancer registration, course of treatment, and diagnosis throughout LRCs also limit the influence on screening services as well as their evaluation, and this must therefore be strengthened simultaneously.

Regular screening is an effective way of detecting $\mathrm{BC}$ [11]. Furthermore, the risk of BC-related mortality rates is significantly lower among women in developed countries who had experienced with BCS [19]. Despite the benefits of screening, the utilisation of BCS services are relatively low in LRCs, compared to high income countries (HICs) [11, 12]. Factors that can influence participation in BCS services vary in different countries' settings [20]. Some studies have found that socioeconomic factors (such as age distribution, marital status, socioeconomics group) are the leading driving force behind utilising BCS services in LRCs [11, 21, 22]. Apart from socio-demographic and economic factors, access to health care services, and health insurance coverage are significantly correlated with higher utilisation of BCS services [23, 24]. In addition, screening behaviors [25], prior knowledge [26], and lack of access to a physician [27] are more likely to influence women's participation in BCS services. Religion, cultural beliefs, social barriers, and ethnicity related factors are also the leading factors responsible for the lower use of BCS services [28, 29].

Some limitations have been observed in previous research that has focused on the determinants of BCS services. The most common limitations are small populations and/or limited study settings (e.g., targeting only a particular region in a country). Central policymaking that has aimed to prevent the burden of $\mathrm{BC}$ based on the outcomes of small study settings is problematic across countries, and this is part of an ongoing debate about breast cancer-related research [30]. 
Therefore, it is important to conduct large-scale studies the findings of which can offer generalisations of the use of BCS services among women. To provide national efforts to decline the incidence of women's cancers (e.g., breast cancer), studies required to generate evidence in terms of specific and estimable information about adequate cancer screening services.

The present study analysed data from 140,974 reproductive women and living in 14 LRCs to examine the current distribution of BCS use and identify potential factors that influence screening use. The findings may offer understanding for evidential priority health interventions across the ongoing country-specific health system. Additionally, significant findings are deliberated considering national health policy in these low-resource countries. This study aimed to indentify the distribution of utilisation of BCS services and to investigate the predictors that have a significant influence on BCS services among women in low-resource settings.

\section{Methods}

\section{Study design}

The design of the study was cross sectional, using the latest Demographic and Health Survey (DHS) data. Data were generated from the latest DHS, including 14 LRCs from 2008 to 2016 [31-44]. The present study was a sub-study, which was generated from the latest DHS survey. Health, demographic, and health care services associated data were captured in this survey, in the context of mostly LRCs. The details of the survey were explained elsewhere [31-44].

\section{Sampling and sample size calculation}

In DHS surveys, a two-stage cluster sampling was occupied [45]. During the first stage, primary sampling units (PSUs) were drawn from a frame respondent list with probability proportional to a size measure. A PSU was commonly a geographically area, named an enumeration area (EA), including a number of households that were made from the recent population census. A number of households were chosen from a list of households pointedly as part of an introducing technique in the selected PSUs in the second stage. The required sample size was estimated and explained elsewhere [45], using the following three equations

$$
\begin{aligned}
& n_{o p t}=\frac{C}{c_{1}+c_{2} m_{o p t}} \\
& C=c_{1} n+c_{2} n m \\
& m_{o p t}=\sqrt{\frac{(1-\rho) c_{1}}{\rho c_{2}}}
\end{aligned}
$$

where, $n_{\text {opt }}$ was denoted estimated sample, $C$ was defined the aggregated cost of the survey, $c_{1}$ and $c_{2}$ were explained the unit cost per interview and the unit cost per interview, respectively. $n$ was denoted the total amount of PSUs, $m$ was the number of respondents in each PSU, and $\rho$ was defined the intracluster correlation.

\section{Data collection procedure}

Data were collected from target participants. The target participants were the reproductive women (e.g., 15 to 49 years' group). Participants were surveyed using the DHS survey instruments. Quantitative structural questionnaires were used to collect data by Measure DHS retrospectively. The total number of study participants was 140,974 reproductive women living in 14 LRCs (Fig. 1).

\section{Study settings}

The disease, screening knowledge, practices, or outcomes related questions were asked across all 14 LRCs. The DHS surveys have been implemented across 90 countries, breast cancer screening questions occurred in only 18 of them. Breast cancer questions (have been added into relatively few DHS surveys, but their absolute inclusion has increased since 1984. Of these countries, data on the utilisation of BCS services were considered from 14 LRCs [31-44]: Albania (survey years: 2008-09), Burkina Faso (survey year: 2010), Colombia (survey year: 2015), Ivory Coast (survey years: 2011-12), Dominican Republic (survey year: 2013), Egypt (survey year: 2015), Honduras (survey years: 2011-12), India (survey years: 2015-16), Jordan (survey year: 2012), Kenya (survey year: 2015), Lesotho (survey year: 2014), Namibia (survey year: 2013), Philippines (survey year: 2013), and Tajikistan (survey year: 2012) (Table 1). However, the four countries (e.g., Equatorial Guinea, Peru, Armenia, and Brazil) were excluded from this study due to their data not being publicly accessible, inadequate information related to our study variables, and obsolete data, so in each case the data were incomplete. Study countries that were distributed across four international geographical lens based on availability of survey data (Fig. 1).

\section{Description of study variables Dependent variables}

The use of BCS services served as the dependent variable. As part of data collection on BCS services, the participants were asked questions by the DHS trained surveyor [31-44]. The dependent variable (i.e., the ever use of BCS practice) was restricted to DHS data, which was of a quantitative cross-sectional nature, based on the participants' self-reported responses. For a particular study country, only one question related to the ever utilisation of breast cancer screening services (or if they had 


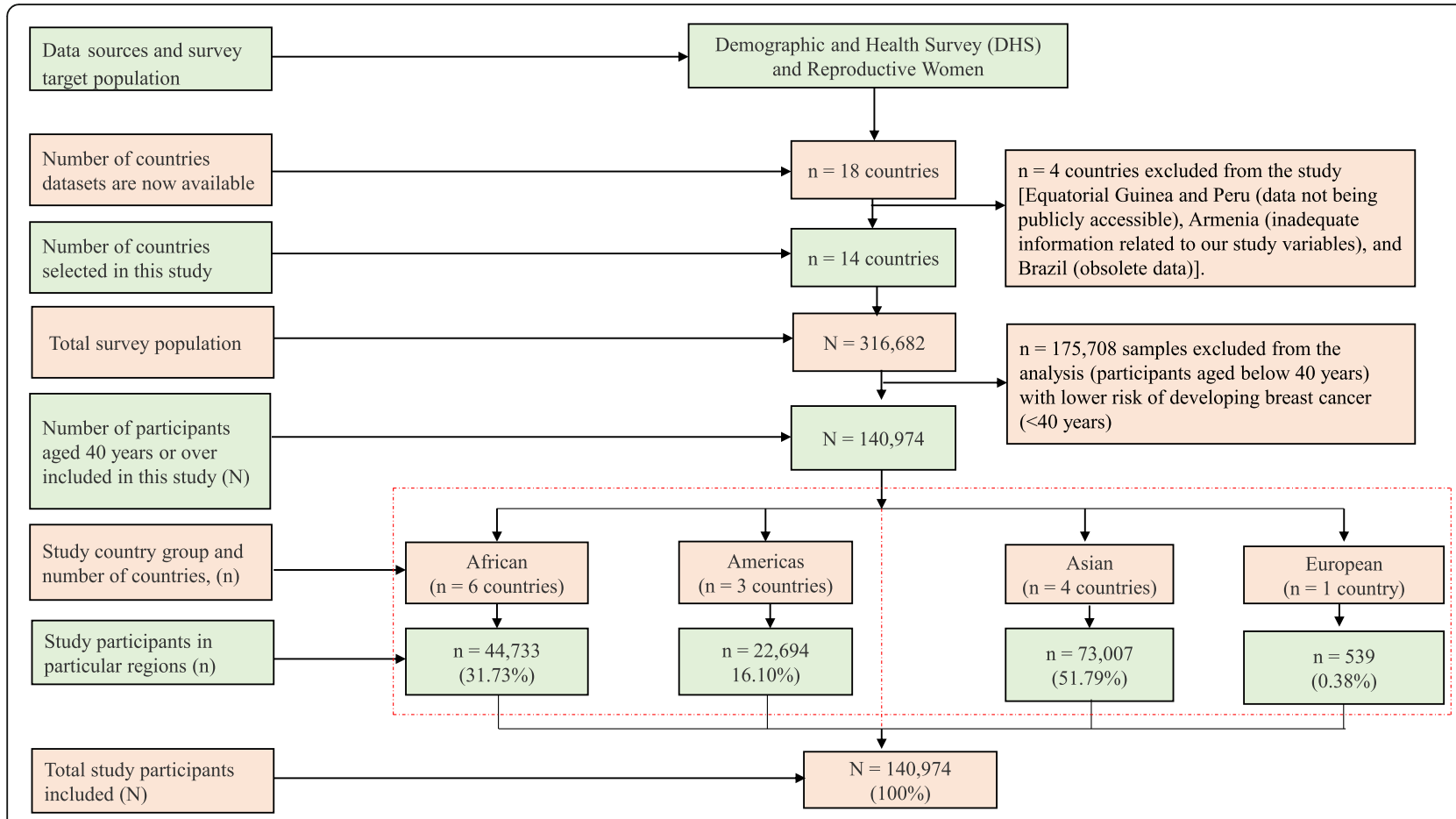

Fig. 1 Distribution of study sample

ever had a breast examination) was identified in the DHS datasets [46]. According to the DHS guideline, the dependent variable was expressed as a dichotomous response ('yes' if the participants had ever used a breast cancer screening service or had ever had a breast examination or 'no' otherwise).

\section{Explanatory variables}

Explanatory variables were selected from the available data sources that were validated based on published research articles on breast cancer screening, epidemiological studies [23, 47-57]. Different explanatory variables were selected for each factor. The predisposing

Table 1 Distribution of study sample

\begin{tabular}{|c|c|c|c|c|c|}
\hline \multirow[t]{2}{*}{ Study country } & \multirow{2}{*}{$\begin{array}{l}\text { Survey } \\
\text { year }\end{array}$} & \multirow{2}{*}{$\begin{array}{l}\text { Number of participants } \\
\text { weighted sample, }(n)\end{array}$} & \multirow{2}{*}{$\begin{array}{l}\text { The utilisation of BCS services } \\
\text { weighted percentage, }(\%)\end{array}$} & \multicolumn{2}{|c|}{ 95\% confidence interval $(\mathrm{Cl})$} \\
\hline & & & & Low bound & Upper bound \\
\hline Albania & 2008-09 & 539 & 80.82 & 77.28 & 83.93 \\
\hline Burkina Faso & 2010 & 473 & 10.56 & 8.09 & 13.68 \\
\hline Colombia & 2015 & 3075 & 25.26 & 23.76 & 26.83 \\
\hline Cote d'Ivoire & $2011-12$ & 5382 & 5.27 & 4.70 & 5.90 \\
\hline Dominican Republic & 2013 & 6643 & 10.28 & 9.57 & 11.03 \\
\hline Egypt & 2015 & 16,973 & 1.84 & 1.64 & 2.05 \\
\hline Honduras & $2011-12$ & 12,975 & 20.36 & 19.67 & 21.06 \\
\hline India & 2015-16 & 43,502 & 5.63 & 5.41 & 5.85 \\
\hline Jordan & 2012 & 18,255 & 36.67 & 35.98 & 37.37 \\
\hline Kenya & 2015 & 11,847 & 24.61 & 23.85 & 25.40 \\
\hline Lesotho & 2014 & 3993 & 8.47 & 7.64 & 9.37 \\
\hline Namibia & 2013 & 6065 & 37.80 & 36.59 & 39.03 \\
\hline Phipillines & 2013 & 9384 & 7.08 & 6.58 & 7.62 \\
\hline Tajikistan & 2012 & 1866 & 63.70 & 61.49 & 65.85 \\
\hline Overall & 2008-16 & 140,974 & 15.41 & 15.22 & 15.60 \\
\hline
\end{tabular}


factors were considered based on participant's age, education, household head, the age at first birth, and parity. All the predictors under predisposing factors were categorical variables. Age was categorised into two groups: 40 to 44 years or $\geq 45$ years at high risk of occurring BC. Education was classified as illiterate, primary education, secondary education, or higher education. The gender of the household head was defined as male-headed or female-headed. The age of the respondents at first birth was distributed into four groups: < 18 years, $18-20$ years, $21-25$ years, and $>25$ years old. The number of childbirths were recoded into three groups: $<4$ births, $4-5$ births, and $>5$ births. Household access to mass media coverage and the status of health insurance coverage served as proxies of enabling factors. Media coverage was denoted as 'yes' or 'no'. The status of health insurance was dichotomous: 'yes' if the household was insured, and 'no' if uninsured. Another factor, the condition of participants' body mass index (BMI) was categorised into three groups: underweight, healthy weight, and overweight. BMI was used to measure the participants' weight status in the following way: underweight $\left(\leq 18.5 \mathrm{~kg} / \mathrm{m}^{2}\right)$, healthy weight $(18.51-24.99 \mathrm{~kg} /$ $\left.\mathrm{m}^{2}\right)$, overweight $\left(25-29.99 \mathrm{~kg} / \mathrm{m}^{2}\right)$, and obese $(\geq 30.00$ $\mathrm{kg} / \mathrm{m}^{2}$ ). Another important control variable, the participant's residence, was classified as urban or rural, and these factors were dichotomous. In the context of LRCs, urban residence covers cities and towns while rural residence includes villages and hamlets. DHS has developed a wealth index using ownership of durable assets [58], which has demonstrated sound psychometric properties [59]. This wealth index variable served as another predictor in the model. The wealth index was classified such as poorest $\left(\mathrm{Q}_{1} ; 20 \%\right.$ lowest), poorer $\left(\mathrm{Q}_{2}\right)$, middle $\left(\mathrm{Q}_{3}\right)$, richer $\left(\mathrm{Q}_{4}\right)$, and richest $\left(\mathrm{Q}_{5} ; 20 \%\right.$ highest).

\section{Data analysis}

In the descriptive analyses, the participant's characteristics were presented using frequencies (n) and percentages (\%). The category level found to be at the lower risk for using BCS services was considered as the reference catagory to construct unadjusted and adjusted odds ratios (ORs) using multivariate logistic regression analysis, with a $95 \%$ CI. A series of diagnostics were tested in the analytical exploration. For instance, the Hosmer and Lemeshow statistic used to execute the goodness of fit test for model [60]. The variance inflation factor (VIF) was also used to detect if any multicollinearity existed among explanatory variables in the model [61]. The ROC (receiver operating characteristic) curve was used to ensure the best predictive power of the fitted model [62]. The sampling weight was adjusted in the analyses, which was derived from the DHS data [63]. Data analysis was performed using Stata/SE 13. A p-value of 0.05 or below was considered a significant level in this study.

\section{Results}

Characteristics of the participants

Approximately $47.25 \%$ of the total participants were aged $40-44$ years, whereas $52.75 \%$ were aged 45 years or more (Table 2). Fifty-nine percent of all participants had 'no formal or only primary level educational background', combined, whereas approximately only $10 \%$ of participants had completed higher education. A high proportion of participants had no formal education in Asian countries ( 36\%), followed by $29 \%$ in African countries. Furthermore, the overall illiteracy rate was found to be only $29.08 \%$. Approximately two-third of households were male-headed, a high proportion was observed in the European country (97.63\%), followed by Asian countries (85.9\%), and African countries (71.97\%). Approximately $67 \%$ of women had delivered four children or more. Only $22.61 \%$ of participants had insured, and $59 \%$ of women were overweight $(26 \%)$ or obese (31\%). Survey results also revealed that nearly $55 \%$ of women lived in a rural community, with the highest proportion found in African countries (65\%), followed by $59 \%$ in the European country, 55\% in Asian countries, and the lowest in Americas countries (37\%). About 38\% of respondents were from a low socio-economic status background.

\section{The utilisation of BCS services across geographical areas}

The overall utilisation of BCS services was $15.41 \%$ (Table 3 ), whereas the utilisation rate was comparatively higher among participants aged 40 to 44 years (16.43\%), compared to participants aged 45 years or over (14.49\%). The utilisation of BCS services varied across reagions, for instance, $81.10 \%$ in the European country, $18.61 \%$ in Asian countries, $14.30 \%$ in American countries, and 14.29\% in African countries. Several countries had a lower utilisation rate of BCS services. For example, the screening participation rate was less than 11\% in Burkina Faso, the Dominican Republic, Egypt, India, Lesotho, and in the Philippines. The utilisation of screening services increased with higher levels of education among participants, for both the following age group: 40 to 44 years and $\geq 45$ years old. For instance, overall only $6 \%$ of women (i.e., $6.73 \%$ of women aged 40 to 44 years and $5.78 \%$ of women aged 45 years or over) utilised screening services who had no formal education, whereas $29 \%$ of higher educated women (i.e., $32.97 \%$ of women aged 40 44 years and $27.27 \%$ of women aged 45 years or over) utilised BCS services. The use of BCS services among women aged 40 to 44 years from female-headed households (18.38\%) was slightly higher compared with the use of BCS services among women aged 45 years or over 
Table 2 Background characteristics of study participants

\begin{tabular}{|c|c|c|c|c|c|}
\hline \multirow{2}{*}{$\begin{array}{l}\text { Participants } \\
\text { characteristics }\end{array}$} & \multicolumn{4}{|c|}{ International geographical regions } & \multirow{2}{*}{$\begin{array}{l}\text { Full sample, } \\
\text { n (\%) }\end{array}$} \\
\hline & $\begin{array}{l}\text { Americas, } \\
\mathrm{n}(\%)\end{array}$ & $\begin{array}{l}\text { Asian, } \\
\mathrm{n}(\%)\end{array}$ & $\begin{array}{l}\text { African, } \\
\text { n (\%) }\end{array}$ & $\begin{array}{l}\text { European, } \\
\text { n (\%) }\end{array}$ & \\
\hline \multicolumn{6}{|l|}{ Age in years } \\
\hline 40-44 years & $11,401(50.24)$ & $31,468(43.1)$ & $23,344(52.19)$ & $395(73.25)$ & $66,608(47.25)$ \\
\hline$\geq 45$ years & $11,293(49.76)$ & $41,539(56.9)$ & $21,388(47.81)$ & $144(26.75)$ & $74,365(52.75)$ \\
\hline \multicolumn{6}{|l|}{ Educational level } \\
\hline No education & $1519(6.70)$ & $26,552(36.37)$ & $12,916(28.87)$ & $3(0.57)$ & $40,990(29.08)$ \\
\hline Primary & $13,289(58.56)$ & $12,983(17.78)$ & 15,739 (35.19) & $279(51.79)$ & $42,290(30.00)$ \\
\hline Secondary & $5348(23.56)$ & $24,838(34.02)$ & $13,299(29.73)$ & 215 (39.92) & $43,699(31.00)$ \\
\hline Higher & $2538(11.18)$ & $8629(11.82)$ & $2779(6.21)$ & $42(7.73)$ & 13,988 (9.92) \\
\hline \multicolumn{6}{|c|}{ Head of the household } \\
\hline Male & $14,876(65.55)$ & $62,716(85.9)$ & $32,195(71.97)$ & $527(97.63)$ & $11,0314(78.25)$ \\
\hline Female & $7817(34.45)$ & $10,292(14.1)$ & $12,538(28.03)$ & $13(2.37)$ & $30,660(21.75)$ \\
\hline \multicolumn{6}{|c|}{ Respondent's age at 1st birth } \\
\hline$<18$ years & $6389(28.28)$ & $16,940(26.65)$ & $11,047(24.7)$ & $3(0.56)$ & $34,379(26.16)$ \\
\hline $18-20$ years & $7776(34.42)$ & $21,212(33.37)$ & 15,178 (33.93) & $75(14.01)$ & $44,241(33.66)$ \\
\hline $21-25$ years & $5908(26.15)$ & $19,990(31.44)$ & $13,845(30.95)$ & $320(60.00)$ & $40,064(30.48)$ \\
\hline$>25$ years & $2520(11.15)$ & $5430(8.54)$ & $4660(10.42)$ & $136(25.42)$ & $12,747(9.7)$ \\
\hline \multicolumn{6}{|c|}{ Number of childbirths } \\
\hline$<4$ & $8739(38.51)$ & $23,718(37.28)$ & $9943(22.23)$ & $428(79.32)$ & $42,828(32.55)$ \\
\hline $4-5$ & $7082(31.21)$ & $21,125(33.2)$ & $15,056(33.66)$ & $98(18.24)$ & $43,362(32.95)$ \\
\hline$>5$ & $6873(30.28)$ & $18,780(29.52)$ & $19,734(44.11)$ & $13(2.44)$ & $45,400(34.50)$ \\
\hline \multicolumn{6}{|c|}{ Mass media exposure } \\
\hline No & $1376(6.06)$ & $13,856(18.98)$ & $8654(19.35)$ & $9(1.61)$ & 23,895 (16.95) \\
\hline Yes & 21,318 (93.94) & $59,151(81.02)$ & $36,079(80.65)$ & $531(98.39)$ & $11,7079(83.05)$ \\
\hline \multicolumn{6}{|c|}{ Health insurance coverage } \\
\hline No & $13,704(69.88)$ & $30,809(70.82)$ & $38,953(87.09)$ & 409 (75.78) & $83,874(77.39)$ \\
\hline Yes & $5906(30.12)$ & $12,694(29.18)$ & $5773(12.91)$ & $131(24.22)$ & $24,504(22.61)$ \\
\hline \multicolumn{6}{|l|}{ Body mass index } \\
\hline Under weight & $230(1.18)$ & $4980(8.92)$ & $1401(3.88)$ & $4(0.73)$ & $6615(5.91)$ \\
\hline Normal weight & $4646(23.82)$ & $22,948(41.12)$ & $10,075(27.93)$ & $208(38.56)$ & $37,877(33.84)$ \\
\hline Overweight & $6898(35.37)$ & $15,801(28.31)$ & $9890(27.42)$ & $225(41.71)$ & $32,814(29.32)$ \\
\hline Obese & $7728(39.62)$ & $12,082(21.65)$ & $14,709(40.77)$ & $103(19.01)$ & $34,621(30.93)$ \\
\hline \multicolumn{6}{|l|}{ Community } \\
\hline Urban & $14,376(63.35)$ & $33,073(45.3)$ & $15,612(34.90)$ & $222(41.19)$ & $63,283(44.89)$ \\
\hline Rural & $8318(36.65)$ & $39,934(54.7)$ & $29,121(65.10)$ & $317(58.81)$ & $77,690(55.11)$ \\
\hline \multicolumn{6}{|l|}{ Wealth quintile } \\
\hline$Q_{1}$ (Poorest 20\%) & $3552(15.65)$ & $11,835(16.21)$ & $9690(21.66)$ & $98(18.14)$ & 25,175 (17.86) \\
\hline$Q_{2}$ & $4135(18.22)$ & $14,552(19.93)$ & $9253(20.69)$ & $108(20.10)$ & $28,048(19.90)$ \\
\hline$Q_{3}$ & $5265(23.2)$ & $15,321(20.99)$ & $8821(19.72)$ & $131(24.22)$ & 29,538 (20.95) \\
\hline$Q_{4}$ & $4877(21.49)$ & $15,884(21.76)$ & $8388(18.75)$ & $104(19.24)$ & $29,253(20.75)$ \\
\hline$Q_{5}$ (Richest 20\%) & $4866(21.44)$ & $15,415(21.11)$ & $8580(19.18)$ & $99(18.30)$ & $28,960(20.54)$ \\
\hline Total observations & $22,694(16.10)$ & 73,007 (51.79) & $44,733(31.73)$ & $539(0.38)$ & $140,974(100)$ \\
\hline
\end{tabular}

All estimates were sampling weight adjusted 
Table 3 Distribution of the utilisation of BCS services across geographical regions

\begin{tabular}{|c|c|c|c|c|c|c|c|c|c|c|}
\hline \multirow{3}{*}{$\begin{array}{l}\text { Participants } \\
\text { characteristics }\end{array}$} & \multicolumn{8}{|c|}{ The utilisation of BCS services, (\%) } & \multirow{2}{*}{\multicolumn{2}{|c|}{ Overall }} \\
\hline & \multicolumn{2}{|c|}{ Americas } & \multicolumn{2}{|l|}{ Asian } & \multicolumn{2}{|c|}{ African } & \multicolumn{2}{|c|}{ European } & & \\
\hline & $\begin{array}{l}40-44 \\
\text { years }\end{array}$ & $\begin{array}{l}\geq 45 \\
\text { years }\end{array}$ & $\begin{array}{l}40-44 \\
\text { years }\end{array}$ & $\begin{array}{l}\geq 45 \\
\text { years }\end{array}$ & $\begin{array}{l}40-44 \\
\text { years }\end{array}$ & $\begin{array}{l}\geq 45 \\
\text { years }\end{array}$ & $\begin{array}{l}40-44 \\
\text { years }\end{array}$ & $\begin{array}{l}\geq 45 \\
\text { years }\end{array}$ & $\begin{array}{l}40-44 \\
\text { years }\end{array}$ & $\begin{array}{l}\geq 45 \\
\text { years }\end{array}$ \\
\hline \multicolumn{11}{|l|}{ Educational level } \\
\hline No education & 5.66 & 11.58 & 7.83 & 6.55 & 4.89 & 3.12 & 0.00 & 100 & 6.73 & 5.78 \\
\hline Primary & 13.21 & 17.28 & 7.35 & 8.86 & 16.14 & 16.29 & 71.73 & 76.28 & 13.63 & 14.05 \\
\hline Secondary & 17.81 & 30.12 & 23.85 & 18.71 & 17.89 & 18.57 & 88.30 & 88.73 & 21.53 & 20.22 \\
\hline Higher & 19.38 & 34.92 & 39.73 & 26.01 & 26.30 & 24.69 & 98.00 & 100 & 32.97 & 27.27 \\
\hline \multicolumn{11}{|c|}{ Head of the household } \\
\hline Male & 14.42 & 22.78 & 17.76 & 13.50 & 12.21 & 10.10 & 79.48 & 84.08 & 15.92 & 13.95 \\
\hline Female & 15.48 & 18.99 & 18.06 & 10.23 & 20.20 & 20.92 & 100.00 & 33.25 & 18.38 & 16.36 \\
\hline \multicolumn{11}{|c|}{ Respondent's age at 1st birth } \\
\hline$<18$ years & 12.10 & 15.74 & 9.23 & 8.08 & 12.17 & 12.20 & 40.96 & 100 & 10.74 & 10.79 \\
\hline $18-20$ years & 13.65 & 20.39 & 18.48 & 12.95 & 15.17 & 13.11 & 78.71 & 78.02 & 16.57 & 14.30 \\
\hline $21-25$ years & 17.07 & 24.46 & 23.54 & 18.44 & 13.90 & 14.10 & 79.61 & 82.94 & 19.71 & 18.15 \\
\hline$>25$ years & 19.79 & 29.57 & 30.12 & 21.83 & 17.78 & 14.19 & 82.52 & 83.07 & 23.78 & 21.26 \\
\hline \multicolumn{11}{|l|}{ Number of childbirths } \\
\hline$<4$ & 18.87 & 29.09 & 9.93 & 7.45 & 18.39 & 18.84 & 81.40 & 87.02 & 15.21 & 14.10 \\
\hline $4-5$ & 14.67 & 19.61 & 21.41 & 13.70 & 13.91 & 12.66 & 77.72 & 64.59 & 17.71 & 14.35 \\
\hline$>5$ & 7.93 & 15.50 & 25.51 & 23.86 & 12.26 & 11.47 & 57.25 & 100 & 17.23 & 17.24 \\
\hline \multicolumn{11}{|l|}{ Mass media exposure } \\
\hline No & 11.21 & 12.08 & 8.77 & 6.73 & 12.34 & 11.08 & 28.67 & 100 & 10.41 & 8.40 \\
\hline Yes & 14.99 & 22.03 & 19.92 & 14.45 & 14.85 & 13.79 & 80.92 & 82.90 & 17.68 & 15.72 \\
\hline \multicolumn{11}{|c|}{ Health insurance coverage } \\
\hline No & 13.68 & 20.30 & 7.33 & 6.03 & 11.58 & 10.75 & 75.98 & 81.06 & 11.03 & 10.51 \\
\hline Yes & 16.69 & 17.06 & 3.90 & 2.87 & 33.76 & 29.74 & 92.05 & 90.28 & 15.71 & 12.07 \\
\hline \multicolumn{11}{|l|}{ Body mass index } \\
\hline Under weight & 15.90 & 12.87 & 6.80 & 6.37 & 14.95 & 13.12 & 0.00 & 0.00 & 8.99 & 7.90 \\
\hline Normal weight & 12.47 & 12.64 & 11.16 & 7.83 & 15.79 & 16.16 & 80.24 & 71.89 & 13.32 & 10.51 \\
\hline Overweight & 15.58 & 20.78 & 20.82 & 10.14 & 15.82 & 13.56 & 80.26 & 96.95 & 18.73 & 13.60 \\
\hline Obese & 14.98 & 22.15 & 21.87 & 24.52 & 9.42 & 8.26 & 81.80 & 82.20 & 15.18 & 17.29 \\
\hline \multicolumn{11}{|l|}{ Community } \\
\hline Urban & 16.87 & 25.51 & 25.08 & 19.00 & 19.18 & 17.12 & 89.95 & 88.56 & 21.91 & 20.16 \\
\hline Rural & 11.19 & 14.18 & 11.00 & 8.45 & 11.70 & 11.29 & 73.74 & 77.99 & 11.74 & 10.08 \\
\hline \multicolumn{11}{|l|}{ Wealth quintile } \\
\hline$Q_{1}$ (Poorest 20\%) & 7.79 & 12.19 & 17.86 & 13.80 & 8.03 & 5.81 & 67.04 & 74.21 & 12.84 & 10.71 \\
\hline$Q_{2}$ & 12.77 & 16.81 & 14.65 & 10.88 & 12.59 & 9.68 & 72.48 & 58.81 & 14.00 & 11.45 \\
\hline$Q_{3}$ & 10.97 & 14.15 & 16.76 & 12.01 & 12.23 & 14.63 & 79.59 & 84.23 & 14.56 & 13.28 \\
\hline Q4 & 14.84 & 22.63 & 17.76 & 13.54 & 17.44 & 14.32 & 83.26 & 95.93 & 17.42 & 15.31 \\
\hline$Q_{5}$ (Richest 20\%) & 25.37 & 39.11 & 22.06 & 14.71 & 22.55 & 23.01 & 99.16 & 87.54 & 23.30 & 20.72 \\
\hline $\begin{array}{l}\text { Total participants, } \\
\%\end{array}$ & 14.77 & 21.41 & 17.79 & 12.99 & 14.34 & 13.30 & 79.99 & 83.09 & 16.43 & 14.49 \\
\hline Overall, \% (95\% Cl) & \multicolumn{2}{|c|}{$\begin{array}{l}14.30 \\
(13.67,14.96)\end{array}$} & \multicolumn{2}{|c|}{$\begin{array}{l}18.61 \\
(18.16,19.06)\end{array}$} & \multicolumn{2}{|c|}{$\begin{array}{l}14.29 \\
(13.87,14.74)\end{array}$} & \multicolumn{2}{|c|}{$\begin{array}{l}81.10 \\
(76.85,84.73)\end{array}$} & \multicolumn{2}{|c|}{$\begin{array}{l}15.41 \\
(15.22-15.60)\end{array}$} \\
\hline
\end{tabular}


(16.36\%). Furthermore, approximately $16 \%$ of women from insured households aged 40-44 years used BCS services. Among participants ( $\geq 45$ years old or over), with the highest proportion observed in American countries (49.46\%), followed by $30.97 \%$ in African countries and the lowest in Asian countries (2.87\%). Similarly, the use of screening services among women was very low irrespective of BMI status (e.g., 8.43\% for underweight, $11.85 \%$ for a healthy weight, $16 \%$ for overweight or obese). Regarding geographic location, the higher proportion of participants who lived in urban communities participated in BCS services compared to participants who lived in a rural community. In addition, the overall use of BCS services was found to be highest in the wealthiest socio-economic status households (22\%), followed by middle-class households (16\%) and the poorest households (12\%), respectively.

\section{Factors influencing of the use of BCS services}

Predisposing factors, such as education, age at first birth, and female-headed households, showed a significant positive association with higher use of BCS services after controlling other factors (Table 4). The increased level of education of the participants significantly influenced the higher use of BCS services. Higher educated participants were more likely to utilise BCS services $(\mathrm{OR}=$ 2.48, 95\% CI: 2.25-2.73) compared to participants with no formal education. Similar associations were found in African countries $(\mathrm{OR}=3.65,95 \% \mathrm{CI}$ : $3.08-4.32)$, and in the European country $(\mathrm{OR}=3.24,95 \% \mathrm{CI}: 2.83-3.73)$. The study also exhibited that a higher age at first birth was associated with the utilisation of BCS services $(\mathrm{OR}=$ 1.65, 95\% CI: 1.52-1.78). Regarding the head of household, participants from female-headed households were 1.65 times more likely to utilise $\mathrm{BCS}$ services $(\mathrm{OR}=1.65$, $95 \%$ CI: $1.58-1.73)$ compared to participants from maleheaded households.

Participants living in households with access to mass media communication were significantly (1.84 times higher) users of BCS services (OR $=1.84$, 95\% CI: 1.79 1.89) compared with households that did not have exposure to mass media communication. Households with health insurance coverage showed a 1.09 times $(\mathrm{OR}=$ 1.09, 95\% CI: 1.04-1.14) higher use of BCS services compared to households without health insurance coverage. Richest and moderate economic situation were associated with 2.01 times $(\mathrm{OR}=2.01,95 \% \mathrm{CI}$ : 1.84-2.20) and 1.43 times $(\mathrm{OR}=1.43,95 \% \mathrm{CI}$ : $1.31-1.55)$ higher use of BCS services, compared to poorest households. Additionally, the study found that the use of BCS services among obese participants was $11 \%(\mathrm{OR}=0.89,95 \%$ CI: 0.84-0.94) lower compared to their healthy weight peers after controlling other factors. Furthermore, women who lived in urban communities used more screening services $(\mathrm{OR}=1.20,95 \% \mathrm{CI}$ : $1.14-1.26)$ compared with women who lived in rural communities.

\section{Discussion}

The results show that the overall utilisation of BCS services in the 14 LRCs was $15.41 \%$ (95\% CI: $15.22-$ $15.60 \%$ ), varying from $81.10 \%$ (95\% CI: 76.85 to $84.73 \%$ ) in the European country, $18.61 \%$ (95\% CI: 18.16 to 19.06\%) in Asian countries, $14.30 \%$ (95\% CI: 13.61 to $14.96 \%$ ) in American countries, and 14.29\% (95\% CI: 13.87 to $14.74 \%$ ) in African countries. The utilisation of BCS services varied across countries and geographical areas, influenced by social and cultural norms, religious beliefs, health knowledge, and awareness. Other factors influence the use of BCS services, although the current study focused only on predisposing factors, enabling factors, economic status, and body mass index as the predictors of BCS services. The findings exhibit that the factors that significantly contributed to the likelihood of using BCS services included higher levels of educational background and participants being from a femaleheaded household.

The results indicate that a higher level of education significantly associated women's uptake of breast cancer screening services. This finding is in line with a recent research finding, in which higher educated women were significantly associated with higher utilisation of BCS services compared to participants with lower levels of educational background [23]. Higher edicated women are more aware of health complications and adverse effects of diseases, including reproductive health check-up, screening services (e.g., breast cancer, cervical cancer), and prevention strategies (e.g., screening services, vaccinations), and thus more likely to use the BCS services. Therefore, interventions to increase the participation rates for BCS services may emphasis specifically on those with lower education levels or may focus on increasing women's health education and awareness levels to achieve population-level increments in screening services.

The present study also revealed that participant's household access to mass media coverage were significantly correlated with more utilisation of BCS services. A previous research has found that media exposure was generally cited as the primary vehicles for increasing awareness about breast cancer screening services and early detection strategies, including breast screening or breast examination associated services [22]. This contributes toward improving overall awareness when implementing new interventions correlated to health programs for primary breast cancer detection [62, 63]. Other studies have found that mass media communications were significantly associated with the higher utilisation of cancer screening services [64-68]. Some 
Table 4 Factors influencing the utilisation of BCS services by geographical regions

\begin{tabular}{|c|c|c|c|c|c|c|}
\hline \multirow[t]{2}{*}{ Participants characteristics } & \multicolumn{2}{|l|}{ Americas } & \multicolumn{2}{|l|}{ Asian } & \multicolumn{2}{|l|}{ African } \\
\hline & $\begin{array}{l}\text { Un-adjusted OR (95\% } \\
\text { Cl) }\end{array}$ & $\begin{array}{l}\text { Adjusted OR } \\
(95 \% \mathrm{Cl})\end{array}$ & $\begin{array}{l}\text { Un-adjusted } \\
\text { OR } \\
(95 \% \mathrm{Cl})\end{array}$ & $\begin{array}{l}\text { Adjusted OR } \\
(95 \% \mathrm{Cl})\end{array}$ & $\begin{array}{l}\text { Un-adjusted OR (95\% } \\
\text { Cl) }\end{array}$ & $\begin{array}{l}\text { Adjusted OR } \\
(95 \% \mathrm{Cl})\end{array}$ \\
\hline \multicolumn{7}{|l|}{ Age group } \\
\hline 40-44 years $(=$ ref) & 1.00 & 1.00 & 1.00 & 1.00 & 1.00 & 1.00 \\
\hline$\geq 45$ years & $1.57(1.47,1.68)$ & $1.48(1.37,1.60)$ & $\begin{array}{l}0.69(0.66 \\
0.72)\end{array}$ & $0.76(0.70,0.82)$ & $0.92(0.87,0.97)$ & $0.91(0.85,0.98)$ \\
\hline \multicolumn{7}{|l|}{ Educational level } \\
\hline No education (= ref) & 1.00 & 1.00 & 1.00 & 1.00 & 1.00 & 1.00 \\
\hline Primary & $1.71(1.43,2.04)$ & $1.48(1.22,1.80)$ & $\begin{array}{l}1.19(1.10 \\
1.29)\end{array}$ & $0.67(0.58,0.76)$ & $4.68(4.24,5.16)$ & $3.82(3.39,4.31)$ \\
\hline Secondary & $2.92(2.43,3.50)$ & $1.67(1.35,2.07)$ & $\begin{array}{l}3.54(3.34 \\
3.74)\end{array}$ & $0.83(0.74,0.94)$ & $5.38(4.87,5.93)$ & $3.47(3.05,3.94)$ \\
\hline Higher & $3.41(2.81,4.14)$ & $1.12(0.88,1.43)$ & $\begin{array}{l}6.23(5.84 \\
6.65)\end{array}$ & $1.10(0.84,1.44)$ & $8.29(7.33,9.37)$ & $3.65(3.08,4.32)$ \\
\hline \multicolumn{7}{|c|}{ Gender of the household head } \\
\hline Male (= ref) & 1.00 & 1.00 & 1.00 & 1.00 & 1.00 & 1.00 \\
\hline Female & $0.92(0.86,0.99)$ & $0.99(0.91,1.07)$ & $\begin{array}{l}0.83(0.78 \\
0.89)\end{array}$ & $1.43(1.29,1.59)$ & $2.05(1.94,2.16)$ & $1.81(1.69,1.95)$ \\
\hline \multicolumn{7}{|l|}{ Respondent's age at 1st birth } \\
\hline$<18$ years $(=$ ref $)$ & 1.00 & 1.00 & 1.00 & 1.00 & 1.00 & 1.00 \\
\hline $18-20$ years & $1.25(1.14,1.37)$ & $1.15(1.04,1.27)$ & $\begin{array}{l}1.96(1.83, \\
2.09)\end{array}$ & $1.12(1.01,1.25)$ & $1.19(1.11,1.28)$ & $0.99(0.90,1.08)$ \\
\hline $21-25$ years & $1.62(1.47,1.78)$ & $1.28(1.15,1.44)$ & $\begin{array}{l}2.78(2.61 \\
2.97)\end{array}$ & $1.20(1.08,1.34)$ & $1.17(1.09,1.26)$ & $0.79(0.71,0.87)$ \\
\hline$>25$ years & $2.03(1.81,2.28)$ & $1.40(1.20,1.64)$ & $3.60(3.32,3.9)$ & $1.80(1.51,2.14)$ & $1.38(1.25,1.52)$ & $0.74(0.64,0.84)$ \\
\hline \multicolumn{7}{|l|}{ Number of childbirths } \\
\hline$<4$ (= ref) & 1.00 & 1.00 & 1.00 & 1.00 & 1.00 & 1.00 \\
\hline $4-5$ & $0.67(0.62,0.73)$ & $0.91(0.82,1.00)$ & $\begin{array}{l}2.24(2.12 \\
2.38)\end{array}$ & $1.32(1.20,1.46)$ & $0.67(0.63,0.72)$ & $0.95(0.87,1.04)$ \\
\hline$>5$ & $0.46(0.42,0.50)$ & $0.87(0.77,0.98)$ & $\begin{array}{l}3.49(3.30 \\
3.69)\end{array}$ & $1.53(1.35,1.73)$ & $0.59(0.55,0.63)$ & $0.99(0.89,1.09)$ \\
\hline \multicolumn{7}{|l|}{ Mass media exposure } \\
\hline No (= ref) & 1.00 & 1.00 & 1.00 & 1.00 & 1.00 & 1.00 \\
\hline Yes & $1.72(1.45,2.03)$ & $0.99(0.83,1.19)$ & $\begin{array}{l}2.45(2.29 \\
2.62)\end{array}$ & $0.81(0.72,0.91)$ & $1.25(1.17,1.35)$ & $0.92(0.84,1.01)$ \\
\hline \multicolumn{7}{|l|}{ Health insurance coverage } \\
\hline No (= ref) & 1.00 & - & 1.00 & 1.00 & 1.00 & 1.00 \\
\hline Yes & $0.99(0.91,1.08)$ & & $\begin{array}{l}0.48(0.44 \\
0.54)\end{array}$ & $0.53(0.47,0.59)$ & $3.70(3.47,3.94)$ & $2.25(2.07,2.45)$ \\
\hline \multicolumn{7}{|l|}{ Body mass index } \\
\hline Under weight & $1.15(0.79,1.68)$ & $1.48(1.00,2.19)$ & $\begin{array}{l}0.69(0.61 \\
0.77)\end{array}$ & $0.84(0.73,0.96)$ & $0.86(0.74,1.01)$ & $1.17(0.99,1.38)$ \\
\hline Normal weight $(=$ ref) & 1.00 & 1.00 & 1.00 & 1.00 & 1.00 & 1.00 \\
\hline Overweight & $1.55(1.39,1.72)$ & $1.42(1.28,1.59)$ & $\begin{array}{l}1.74(1.63 \\
1.85)\end{array}$ & $1.03(0.93,1.15)$ & $0.91(0.84,0.98)$ & $0.80(0.73,0.87)$ \\
\hline Obese & $1.59(1.43,1.76)$ & $1.41(1.26,1.57)$ & $\begin{array}{l}2.96(2.78 \\
3.14)\end{array}$ & $1.11(0.96,1.28)$ & $0.51(0.47,0.55)$ & $0.46(0.42,0.51)$ \\
\hline \multicolumn{7}{|l|}{ Community } \\
\hline Urban & $1.86(1.72,2.00)$ & $1.22(1.11,1.35)$ & $2.66(2.55$ & $1.21(1.08,1.34)$ & $1.71(1.62,1.81)$ & $0.94(0.86,1.03)$ \\
\hline
\end{tabular}


Table 4 Factors influencing the utilisation of BCS services by geographical regions (Continued)

\begin{tabular}{|c|c|c|c|c|c|c|}
\hline & & & 2.77) & & & \\
\hline Rural (= ref) & 1.00 & 1.00 & 1.00 & 1.00 & 1.00 & 1.00 \\
\hline Wealth quintile & & & & & & \\
\hline Q1 (Poorest 20\%) (= ref) & 1.00 & 1.00 & 1.00 & 1.00 & 1.00 & 1.00 \\
\hline Q2 & $1.57(1.37,1.80)$ & $1.52(1.29,1.79)$ & $\begin{array}{l}0.76(0.71 \\
0.82)\end{array}$ & $0.82(0.72,0.94)$ & $1.69(1.52,1.87)$ & $1.63(1.44,1.85)$ \\
\hline Q3 & $1.29(1.12,1.48)$ & $1.11(0.94,1.32)$ & $\begin{array}{l}0.87(0.81 \\
0.93)\end{array}$ & $0.82(0.70,0.96)$ & $2.07(1.87,2.28)$ & $1.63(1.44,1.85)$ \\
\hline Q4 & $2.05(1.80,2.34)$ & $1.64(1.38,1.95)$ & $\begin{array}{l}0.96(0.90 \\
1.02)\end{array}$ & $0.85(0.71,1.02)$ & $2.54(2.30,2.80)$ & $2.49(2.18,2.85)$ \\
\hline Q5 (Richest 20\%) & $4.26(3.76,4.82)$ & $3.39(2.84,4.06)$ & $\begin{array}{l}1.15(1.07 \\
1.22)\end{array}$ & $0.83(0.68,1.01)$ & $3.94(3.59,4.32)$ & $3.58(3.08,4.17)$ \\
\hline LR Chi-square (P-value) & & $131.51(P<0.001)$ & & $\begin{array}{l}550.95(P< \\
0.001)\end{array}$ & & $\begin{array}{l}303.15(P= \\
0.005)\end{array}$ \\
\hline Linktest hat-OR (P-value) & & $2.63(P<0.001)$ & & $3.98(P<0.001)$ & & $2.62(P<0.001)$ \\
\hline $\begin{array}{l}\text { Hosmer-Lemeshow statistic } \\
\text { (P-value) }\end{array}$ & & $15.98(P<0.001)$ & & $\begin{array}{l}11.78(P= \\
0.001)\end{array}$ & & $\begin{array}{l}14.54(P= \\
0.002)\end{array}$ \\
\hline Area under ROC curve & & 0.79 & & 0.72 & & 0.75 \\
\hline VIF Mean (Max) & & $3.21(4.56)$ & & $2.45(3.96)$ & & $2.90(4.13)$ \\
\hline Participants characteristics & European & & Overall & & & \\
\hline & $\begin{array}{l}\text { Un-adjusted OR (95\% } \\
\text { Cl) }\end{array}$ & $\begin{array}{l}\text { Adjusted OR (95\% } \\
\text { Cl) }\end{array}$ & Un-adjuste & $\mathrm{R}(95 \% \mathrm{Cl})$ & Adjusted OR (95\% Cl) & \\
\hline Age group & & & & & & \\
\hline 40-44 years $(=$ ref) & 1.00 & - & 1.00 & & 1.00 & \\
\hline$\geq 45$ years & $1.23(0.75,2.03)$ & & $0.86(0.84$ & & $0.91(0.87,0.94)$ & \\
\hline Educational level & & & & & & \\
\hline No education (= ref) & 1.00 & 1.00 & 1.00 & & 1.00 & \\
\hline Primary & $0.95(0.56,1.97)$ & $4.01(3.63,4.43)$ & $2.44(2.32$ & & $2.39(2.25,2.53)$ & \\
\hline Secondary & $1.97(1.56,2.49)$ & $3.55(3.20,3.94)$ & $4.01(3.82$, & & $2.08(1.95,2.21)$ & \\
\hline Higher & $1.57(1.39,1.76)$ & $3.24(2.83,3.73)$ & $6.50(6.16,6$ & & $2.48(2.25,2.73)$ & \\
\hline Gender of the household he & & & & & & \\
\hline Male $(=$ ref $)$ & 1.00 & - & 1.00 & & 1.00 & \\
\hline Female & $1.40(0.29,6.69)$ & & $1.19(1.15$ & & $1.65(1.58,1.73)$ & \\
\hline Respondent's age at 1st birt & & & & & & \\
\hline$<18$ years $(=$ ref $)$ & 1.00 & - & 1.00 & & 1.00 & \\
\hline $18-20$ years & $2.57(0.24,7.29)$ & & $1.51(1.45$ & & $1.19(1.13,1.26)$ & \\
\hline $21-25$ years & $2.86(0.28,8.92)$ & & $1.93(1.85,2$ & & $1.30(1.23,1.38)$ & \\
\hline$>25$ years & $1.35(0.32,4.81)$ & & $2.40(2.27,2$ & & $1.65(1.52,1.78)$ & \\
\hline Number of childbirths & & & & & & \\
\hline$<4$ (= ref) & 1.00 & - & 1.00 & & 1.00 & \\
\hline $4-5$ & $0.59(0.35,1.00)$ & & $1.11(1.07$ & & $1.25(1.18,1.31)$ & \\
\hline$>5$ & $0.33(0.10,1.02)$ & & $1.21(1.17$ & & $1.48(1.40,1.57)$ & \\
\hline Mass media exposure & & & & & & \\
\hline No $(=r e f)$ & 1.00 & 1.00 & 1.00 & & 1.00 & \\
\hline Yes & $6.02(1.54,23.59)$ & $1.86(1.79,1.93)$ & $1.93(1.85,2$ & & $1.84(1.79,1.89)$ & \\
\hline Health insurance coverage & & & & & & \\
\hline No $(=r e f)$ & 1.00 & 1.00 & 1.00 & & 1.00 & \\
\hline Yes & $3.19(1.65,6.19)$ & $2.60(2.42,2.80)$ & $1.32(1.27$ & & $1.09(1.04,1.14)$ & \\
\hline
\end{tabular}


Table 4 Factors influencing the utilisation of BCS services by geographical regions (Continued)

\begin{tabular}{|c|c|c|c|c|}
\hline \multicolumn{5}{|l|}{ Body mass index } \\
\hline Under weight & ns & & $0.68(0.62,0.75)$ & $0.96(0.87,1.06)$ \\
\hline Normal weight $(=$ ref) & 1.00 & - & 1.00 & 1.00 \\
\hline Overweight & $1.49(0.92,2.43)$ & & $1.43(1.37,1.49)$ & $1.04(0.98,1.09)$ \\
\hline Obese & $1.27(0.70,2.32)$ & & $1.44(1.38,1.51)$ & $0.89(0.84,0.94)$ \\
\hline \multicolumn{5}{|l|}{ Community } \\
\hline Urban & $2.88(1.75,4.75)$ & $1.13(1.05,1.22)$ & $2.19(2.12,2.25)$ & $1.20(1.14,1.26)$ \\
\hline Rural (= ref) & 1.00 & 1.00 & 1.00 & 1.00 \\
\hline \multicolumn{5}{|l|}{ Wealth quintile } \\
\hline Q1 (Poorest 20\%) (= ref) & 1.00 & 1.00 & 1.00 & 1.00 \\
\hline Q2 & $1.07(0.59,1.94)$ & $1.44(1.30,1.60)$ & $1.08(1.03,1.14)$ & $1.26(1.17,1.36)$ \\
\hline Q3 & $1.96(1.06,3.62)$ & $1.46(1.32,1.63)$ & $1.21(1.15,1.27)$ & $1.17(1.08,1.26)$ \\
\hline Q4 & $3.40(1.63,7.07)$ & $1.65(1.47,1.84)$ & $1.46(1.39,1.53)$ & $1.43(1.31,1.55)$ \\
\hline Q5 (Richest 20\%) & $1.27(1.08,3.17)$ & $2.05(1.81,2.32)$ & $2.10(2.00,2.20)$ & $2.01(1.84,2.20)$ \\
\hline LR Chi-square (P-value) & & $130.46(P<0.005)$ & & $375.12(P<0.001)$ \\
\hline Linktest hat-OR (P-value) & & $2.98(P<0.001)$ & & $3.26(P<0.005)$ \\
\hline $\begin{array}{l}\text { Hosmer-Lemeshow statistic ( } P \text { - } \\
\text { value) }\end{array}$ & & $75.19(P<0.002)$ & & 20.62 \\
\hline Area under ROC curve & & 0.80 & & 0.80 \\
\hline VIF Mean (Max) & & $3.16(3.15)$ & & $3.20(3.51)$ \\
\hline
\end{tabular}

interventions based on media communication to increase the use of women cancer screening services and screening services have been revealed to improve screening behaviour of women by nearly 4 to $10 \%[66,67]$. Therefore, governments should deliberate initiatives that produce program awareness about breast cancer screening services through extensive broadcast associated health messages, or through modes most likely to be promoted in each country context or geographical lens.

The findings show that women's BMI status was significantly associated with the utilisation of BCS services. In a prior study [24], the researchers also revealed that obese or overweight women utilised $17 \%$ less screening services in comparison with women of healthy weight. However, the risk of $\mathrm{BC}$ was higher in amongst obese women $\left(>35 \mathrm{~kg} / \mathrm{m}^{2}\right)$ [69, 70]. Among older women, obese $\left(\geq 30 \mathrm{~kg} / \mathrm{m}^{2}\right)$ women were associated with higher risk of occurring $\mathrm{BC}$, compared to healthy women, while that relationship tended to be the inverse in reproductive women [51]. More research (e.g., quantitative exploration including randomised control trials, clinical trials, and epidemiological studies) is significantly to investigate the reasons for this lower utilisation so that efforts can be made to promote BCS rates.

The results further showed that women with health insurance coverage were significantly associated with higher utilisation of BCS services compared to their uninsured counterparts. This finding is consistent with the previous finding [71], in which it was found that women from insured households had a 70\% higher utilisation of BCS. Here, the possible reason could be a high out-ofpocket payment that hinders access. Previous research has provided evidence that low incomes, being uninsured, and lack of affordability of healthcare services were significantly correlated with a lower probability of utilising BCS services [71-77]. Thus, the current results provide further evidence in relation to health care systems that do not incorporate community-based healthcare programs. These programs, including chronic disease management, health promotion, and awareness, affordable services, etc., and those who do not make BCS services available as part of existing healthcare packages, are likely to experience lower than optimal screening rates. This, in turn, will lead to a higher breast cancer burden and lower survival rates. Hence, it is necessary to address the financial barriers associated with BCS services amongst the uninsured in low resource countries.

The findings also identified socio-economic status as another significant predictor that makes the richest women more likely to undergo BCS services compared to the poorest women. The conclusion that the participants with the wealthiest economic conditions are significantly more likely the use screening services in lowresource countries aligns with previous results [78-80]. The results further showed that urban residence leads to higher use of BCS services, which is also support with previous research [81]. By contrast, another study has 
revealed that the use of screening services was comparatively high among women living in rural areas [11]. The most common reasons for women in urban communities being more likely to use the BCS services considering affordability, accessibility, and availability of services [8287]. Therefore, accessible screening facilities may increase the use of screening services. Mobile-based screening for cancer should be increased in low-resource settings to target rural area womens' BCS uptake. Other interventions in low-resource settings could include community health workers guided by smartphone applications. This model can play an active and significant role in confirming breast health promotion, which contributes to increasing participation in screening services [87-93].

This study has some limitations. The data were derived from the latest DHS, which is based on selfreported information of respondents. The present study finindgs were derived based on self-reported data that might occur recall and social desirability bias. As a result, there might be a risk that screening-related estimates were over-reported. Further studies might confirm these results. Furthermore, this study was crosssectional in design; hence it can not provide an exploration of causal inferences. Some common quantitative factors that have been used in similar prior studies, such as marital status, past screening behaviors, previous knowledge on screening, religion, cultural beliefs, provider attitude, the side effect of the screening, demand for healthcare, and costs of screening services, were excluded due to the lack of data in the DHS survey. These types of factors should consider in the further study in terms of the health system and societal perspectives, which might significant for policymaker or researchers to develop an appropriate program design or intervention (e.g., patient preferences) to reduce the burden of breast cancer among high risk or disadvantaged communities. Another limitation is that the participants' binary responses did not allow cross-validation of qualitative data. Also, the questions related to the use of BCS services varies across countries, and they depend on country-specific cultural beliefs and social norms. Although, the DHS data are nationally representative and countywide among reproductive women. The present study was a sub-study. The present study participates were women aged 40 or above due to the high risk of breast cancer incidence at this age group. However, the breast screening facility might be localised on region or city of the country.

In this context, the present study constructed based on 14 LRCs where breast cancer screening servicesrelated variables were available. The present study has produced to pooled findings, which incorporate a more precise estimate across possible geographical areas. In the context of the European region, data associated with BCS services are available for only a single country (e.g., Albania). The prevalence and association of BCS services may therefore underestimate or overestimate for this region. Further investigations are necessary to confirm more precise estimates, including additional countries and settings in the European region. The authors have reviewed questions related to breast cancer screening services in the DHS datasets and identified the different forms of questions across the study countries. The dependent variable (i.e., the ever use of BCS practice) was restricted to DHS data based on the various types of items related to breast cancer screening services, which might create a concern about whether the outcomes are combined in an 'overall' estimate.

Despite these limitations, the strength of the study is that it has used nationally representative data that have been gathered following standardised scientific procedures, and public health researchers broadly use these data. The main strength of the present study was the large sample size, which included 140,974 reproductive women in 14 LRCs across international geographical lens. This large sample size may offer more precise estimates as limited settings, or small-scale studies, are only able to draw on a small piece of evidence related to screening services in a regional or community's context. Further, the inclusion of predictors beyond simple demographics is another strength. Finally, this study included new factors such as media exposure and nutritional status to check if any associations existed with the usage of BCS services.

\section{Conclusions}

Breast cancer screening (BCS) services are very important for LRCs where the burden of $\mathrm{BC}$ is generally poorly documented, while its impact on the population is large and growing. To combat this burden, its magnitude must be outlined so that regular screening services for the early detection of $\mathrm{BC}$ can be planned efficiently by standard healthcare facilities, so that prevention mechanisms can be improved. Despite the benefits of BCS services, the utilisation of these services is very low in LRCs, although this varies widely from country to country. The findings show that education, age at first birth, head of household status, mass media communication health insurance coverage, economic status, nutritional status, and rural residence have a positive influence on higher use of BCS services. However, the magnitude of association varies across countries, with wide cultural diversity in the studied countries. The findings emphasize that culturally appropriate promotional campaigns, health awarness, health education programs, and health policy, aimed at these socio-economically and 
geographically disadvantaged women, might be helpful when promoting BCS services.

A better understanding of public healthcare systems, with regards to access to advanced medical technologies or BCS services may help to understand the variations in screening observed. The utilisation of BCS services is advantageous when it is performed in a structured and regular manner in well run public health systems or when the per capita income of the population permits individuals to absorb most of the associated expenses. Country-specific qualitative studies are required to explore the main reasons, challenges, and barriers for the lower use of BCS services in a cross-cultural context.

\section{Abbreviations}

BCS: Breast cancer screening; VIF: Variance Influential Factors; OR: Odds Ratios; Cl: Confidence Interval; DHS: Demographic and Health Survey; LSR: Low-resource country

\section{Acknowledgements}

This research paper was drafted and completed during the first author's PhD research work at University of Southern Queensland, Queensland, Australia. The revision of this manuscript was performed during the first author's postdoctoral research works under the School of Social Science, Western Sydney University, Australia. We would also like to thank the Measure DHS program for providing access to the data utilised in the research.

\section{Authors' contributions}

RAM, AR, KA, and JG contributed in conceptualise of the study; RAM performed data extraction and analyses, under the guidance of AR, KA and JG. RAM and SAK contributed in result interpretation, under the guidance of $A R, K A$ and JG. RAM prepared the first draft All authors contributed during the conceptualization and interpretation of results and substantial revision Revised and finalized the final draft manuscript: RAM, JG, SAK SM, JD, KA and AR. All authors read and approved the final version of the manuscript.

\section{Funding}

No funding grant was received.

\section{Availability of data and materials}

The DHS data are publicly accessible by the Measure DHS.

https://dhsprogram.com/data/

\section{Ethics approval and consent to participate}

Ethical clearance to conduct the DHS survey was acquired from Measure DHS and the Ethics Committee of ICF Macro (Calverton, MD, USA). We analysed the dataset after receiving approval from the Measure DHS program office.

\section{Consent for publication}

Not applicable.

\section{Competing interests}

The authors declare that they have no competing interests in terms of financial and non-financial. Rashidul Alam Mahumud is an Associate Editor of this journal.

\footnotetext{
Author details

'School of Social Sciences, Western Sydney University, Penrith, New South Wales 2751, Australia. ${ }^{2}$ Translational Health Research Institute (THRI), Western Sydney University, Sydney, New South Wales, Australia. ${ }^{3}$ Health Economics and Policy Research, School of Commerce, Centre for Health Research, University of Southern Queensland, Toowoomba, Queensland 4350, Australia. ${ }^{4}$ School of Accounting, Economics and Finance, University of KwaZulu-Natal, Durban 4000, South Africa. ${ }^{5}$ Department of Economics, American International University-Bangladesh, Dhaka 1212, Bangladesh. ${ }^{6}$ School of Psychology and Counselling, University of Southern Queensland,
}

Toowoomba, Queensland 4300, Australia. ${ }^{7}$ Cancer Research Centre, Cancer Council Queensland, Fortitude Valley, Brisbane, QLD 4006, Australia. ${ }^{8}$ Prostate Cancer Research Foundation of Australia, St Leonards, New South Wales 2065, 40, Australia.

Received: 22 May 2019 Accepted: 17 September 2020

Published online: 29 September 2020

\section{References}

1. World Cancer Research Fund/American Institute for Cancer Research. Breast cancer statistics. Washington DC: AICR; 2018. Available at https://www.wcrf. org/dietandcancer/cancer-trends/breast-cancer-statistics.

2. World Health Organization (WHO). Breast Cancer. Geneva; 2018. https:// www.who.int/cancer/prevention/diagnosis-screening/breast-cancer/en/.

3. Ginsburg O, Bray F, Coleman MP, Vanderpuye V, Eniu A, Kotha R, Sarker M, Huong TT, Allemani C, Dvaladze A, Gralow J, et al. The global burden of women's cancers: an unmet grand challenge in global health. Lancet. 2017; 389:847-60. https://doi.org/10.1016/S0140-6736(16)31392-7.

4. Torre LA, Siegel RL, Ward EM, Jemal A. Global cancer incidence and mortality rates and trends - an update. Cancer Epidemiol Biomark Prev. 2016;25(1):16-27. https://doi.org/10.1158/1055-9965.EPI-15-0578.

5. Aminisani N, Fattahpour R, Dastgiri S, Asghari-Jafarabadi M, Allahverdipour $H$. Determinants of breast cancer screening uptake in Kurdish women of Iran. Health Promot Perspect. 2016;6(1):42-6. https://doi.org/10.15171/hpp. 2016.07.

6. Coughlin SS, Ekwueme DU. Breast cancer as a global health concern. Cancer Epidemiol. 2009;33(5):315-8.

7. Youlden DR, Cramb SM, Dunn NA, Muller JM, Pyke CM, Baade PD. The descriptive epidemiology of female breast cancer: an international comparison of screening, incidence, survival and mortality. Cancer Epidemiol. 2012;36(3):237-48. https://doi.org/10.1016/j.canep.2009.10.003.

8. Matro JM, Li T, Cristofanilli M, Hughes ME, Ottesen RA, Weeks JC, et al. Inflammatory breast cancer management in the national comprehensive cancer network: the disease, recurrence pattern, and outcome. Clin Breast Cancer. 2015;15(1):1-7.

9. Hortobagyi GN, de la Garza SJ, Pritchard K, Amadori D, Haidinger R, Hudis CA, Khaled H, Liu MC, Martin M, Namer M, O'shaughnessy JA. The global breast cancer burden: variations in epidemiology and survival. Clinical Breast Cancer. 2005;6(5):391-401.

10. Denny L, Sanjose SD, Mutebi M, Anderson BO, Kim J, Jeronimo J, Herrero R, Yeates K, Ginsburg O, Sankaranarayanan R. Interventions to close the divide for women with breast and cervical cancer between low-income and middle-income countries and high-income countries. Lancet. 2017; 389(10071):861-70.

11. Akinyemiju TF. Socio-economic and health access determinants of breast and cervical cancer screening in low-income countries: analysis of the world health survey. PLoS One. 2012;7(11):e48834. https://doi.org/10.1371/journal. pone.0048834

12. Bray F, Ferlay J, Soerjomataram I, Siegel RL, Torre LA, Jemal A. Global cancer statistics 2018: GLOBOCAN estimates of incidence and mortality worldwide for 36 cancers in 185 countries. CA Cancer J Clin. 2018;68(6):394-424.

13. Institute for Health Metrics and Evaluation (IHME). The Challenge Ahead: Progress and Setbacks in Breast and Cervical Cancer. Seattle: IHME; 2011.

14. Aro AR, De Koning HJ, Absetz P, Schreck M. Two distinct groups of nonattenders in an organized mammography screening program. Breast Cancer Res Treat. 2001;70:145-53.

15. El Saghir NS, Khalil MK, Eid T, El Kinge AR, Charafeddine M, Geara F, et al. Trends in epidemiology and management of breast cancer in developing Arab countries: a literature and registry analysis. Int J Surg. 2007;5:225-33.

16. Knaul FM, Nigenda G, Lozano R, Arreola-Ornelas H, Langer A, Frenk J. Breast cancer in Mexico: a pressing priority. Reprod Health Matters. 2008;16:113-23.

17. Kayhan A, Gurdal SO, Ozaydin N, Cabioglu N, Ozturk E, Ozcinar B, et al. Successful first round results of a Turkish breast Cancer screening program with mammography in Bahcesehir, Istanbul Asian Pacific. J Cancer Prev. 2014;15:1693-7.

18. Othman A, Ahram M, Al-Tarawneh MR, Shahrouri M. Knowledge, attitudes and practices of breast cancer screening among women in Jordan. Health Care Women Int. 2015:36:578-92.

19. Gutnik LA, Matanje-Mwagomba B, Msosa V, Mzumara S, Khondowe B, Moses $A$, et al. Breast cancer screening in low- and middle-income countries: a perspective from Malawi. J Global Oncol. 2016;4(2):1-5. 
20. Chahine G, El Rassy E, Khazzaka A, Saleh K, Rassy N, Khalife N, et al. Characteristics of incident female breast cancer in Lebanon, 1990-2013: descriptive study of 612 cases from a hospital tumor registry. Cancer Epidemiol. 2015;39:303-6. https://doi.org/10.1016/j.canep.2015.03.008.

21. Corbex M, Burton R, Sancho-Garnier H. Breast cancer early detection methods for low and middle income countries: a review of the evidence. Breast. 2012;21(4):428-34

22. Galukande M, Kiguli-Malwadde E. Rethinking breast cancer screening strategies in resource-limited settings. Afr Health Sci. 2010;10(1):89-92.

23. Harford JB. Breast-cancer early detection in low-income and middle-income countries: do what you can versus one size fits all. Lancet Oncol. 2011;12(3): 306-12..

24. Lauby-Secretan B, Scoccianti C, Loomis D, et al. Breast-cancer screeningviewpoint of the IARC working group. N Engl J Med. 2015;372:2353-8.

25. Lee K, Lim HT, Park SM. Factors associated with use of breast cancer screening services by women aged $\geq 40$ years in Korea: the third Korea National Health and nutrition examination survey 2005 (KNHANES III). BMC Cancer. 2010;10(144):1-11.

26. Park MJ, Park EC, Choi KS, Jun JK, Lee HY. Sociodemographic gradients in breast and cervical cancer screening in Korea: the Korean national cancer screening survey (KNCSS) 2005-2009. BMC Cancer. 2011;11(257):1-8.

27. Secginli S, Nahcivan NO. Factors associated with breast cancer screening behaviours in a sample of Turkish women: a questionnaire survey. Int J Nurs Stud. 2006;43(2):161-71.

28. Trinh QD, Li H, Meyer CP, Hanske J, Choueiri TK, Reznor G, Lipsitz SR, Kibel AS, Han PK, Nguyen PL, Menon M. Determinants of cancer screening in Asian-Americans. Cancer Control. 2016;27(8):989-98.

29. Wee CC, McCarthy EP, Davis RB, Phillips RS. Obesity and breast cancer screening: the influence of race, illness burden, and other factors. Journal of general internal medicine 2004; 19(4):324-331. Anwar SL, Tampubolon G, Van Hemelrijck M, Hutajulu SH, Watkins J, Wulaningsih W. determinants of cancer screening awareness and participation among Indonesian women. BMC Cancer. 2018;18(208):1-11.

30. Litaker D, Tomolo A. Association of contextual factors and breast cancer screening: finding new targets to promote early detection. J Women's Health. 2007;16(1):36-45.

31. IIPS \& ICF. India National Family Health Survey (NFHS-4), 2015-16. International Institute for Population Sciences (IIPS) and ICF, India. Mumbai: IIPS; 2017.

32. Ministry of Social Protection. Colombia Demographic and Health Survey 2015. Bogota: Profamilia; 2017.

33. Dushanbe Tajikistan and ICF International. Tajikistan demographic and health survey 2012. Tajikistan and ICF International: Dushanbe; 2012

34. Calverton Maryland and ICF International. Cote d'Ivoire demographic and health survey 2012-13. Calverton: INS/Côte d'Ivoire and ICF International; 2012.

35. Institute of National Statistics; ICF International. Burkina Faso demographic and health survey 2010. Calverton: INSD and ICF International; 2012.

36. Institute of Statistics; Institute of Public Health [Albania] and ICF Macro. Albania Demographic and Health Survey 2008-09. Tirana: Institute of Statistics, Institute of Public Health and ICF Macro; 2010.

37. Ministry of Health [Lesotho] and ICF International. Lesotho Demographic and Health Survey 2014. Maseru: Ministry of Health and ICF International; 2016

38. Kenya National Bureau of Statistics, Ministry of Health, National AIDS Control Council, Kenya Medical Research Institute, National Council for Population and Development. The DHS Program II. Nairobi, Rockville: Kenya Demographic and Health Survey 2014; 2015.

39. ICF International. Dominican Republic demographic and health survey 2013. USA: The Dominican Republic and ICF International; 2015.

40. Ministry of Health and Population [Egypt]; El-Zanaty and Associates [Egypt]; and ICF International. Egypt Demographic and Health Survey 2014. Cairo, Rockville: Ministry of Health and Population and ICF International; 2015.

41. The Namibia Ministry of Health and Social Services (MoHSS) and ICF International. The Namibia Demographic and Health Survey 2013. Windhoek and Rockville: MoHSS and ICF International; 2014.

42. The Philippine Statistics Authority (PSA) [Philippines] and II. Philippines National Demographic and Health Survey 2013. Manila and Rockville: PSA and ICF International; 2014.

43. Department of Statistics and ICF International. Jordan population and family health survey 2012. Calverton: Department of Statistics and ICF International; 2013.

44. Ministry of Health (Honduras); ICF International. Honduras Demographic and Health Survey 2011-12. Honduras: ICF International; 2012.
45. Aliaga A, Ren R. Optimal sample sizes for two-stage cluster sampling in demographic and health surveys. DHS Working Papers No 30, Demographic and Health Research Division, ORC Macro, 11785 Beltsville Drive, Suite 300, Calverton, MD 20705; 2006

46. Viens L, Perin D, Senkomago V, Neri A, Saraiya M. Questions about cervical and breast cancer screening knowledge, practice, and outcomes: a review of demographic and health surveys. J Womens Heal. 2017;26(5):403-12.

47. Kwok C, Endrawes G, Lee CF. Cultural beliefs and attitudes about breast cancer and screening practices among Arabic women in Australia. Cancer Nurs. 2016;39(5):367-74.

48. Boxwala FI, Bridgemohan A, Griffith DM, Soliman AS. Factors associated with breast cancer screening in Asian Indian women in metro-Detroit. J Immigr Minor Health. 2010;12(4):534-43.

49. Harcourt N, Ghebre RG, Whembolua GL, Zhang Y, Osman SW, Okuyemi KS. Factors associated with breast and cervical cancer screening behavior among African immigrant women in Minnesota. J Immigr Minor Health. 2014;16(3):450-6.

50. Vahabi M, Lofters A, Kim E, Wong JPH, Ellison L, Graves E, Glazier RH. Breast cancer screening utilization among women from Muslim majority countries in Ontario, Canada. Prev Med. 2017;105:176-83.

51. Bleyer A, Welch HG. Effect of three decades of screening mammography on breast-cancer incidence. N Engl J Med. 2012;367:1998-2005.

52. Albeshan SM, Mackey MG, Hossain SZ, Alfuraih AA, Brennan PC. Breast cancer epidemiology in gulf cooperation council countries: a regional and international comparison. Clin Breast Cancer. 2018;18(3):e381-92.

53. Bleyer A, Barr R, Hayes-Lattin B, Thomas D, Ellis C, Anderson B. The distinctive biology of cancer in adolescents and young adults. Nat Rev Cancer. 2008:8:1-10

54. Ruddy KJ, Gelber S, Tamimi R, Schapira LS, Come S, Kereakoglow S, et al. Presentation of breast cancer in young women. J Clin Onclol. 2009;27(15): 6608.

55. Partridge $\mathrm{AH}$, Ruddy KJ, Kennedy J, Winer EP. Model program to improve care for a unique cancer population: young women with breast cancer. J Oncol Pract. 2012;8(5):e105-10.

56. Jemal A, Siegel R, Ward E, Murray T, Xu M. Cancer statistics. CA Cancer J Clin. 2007:57:43-66. https://doi.org/10.3322/canjclin.57.1.43.

57. Rivera-franco MM, Leon-rodriguez E. Delays in breast cancer detection and treatment in developing countries. Breast Cancer Basic Clin Res. 2018;12:1-5.

58. Kolenikov S, Angeles G. Socioeconomic status measurement with discrete proxy variables: is principal component analysis a reliable answer? Rev Income Wealth. 2009;55(1):128-65.

59. Kangmennaang J, Mkandawire P, Luginaah I. Breast cancer screening among women in Namibia: explaining the effect of health insurance coverage and access to information on screening behaviours. Glob Health Promot. 2019;26(3):50-61. https://doi.org/10.1177/1757975917727017.

60. Hosmer D, Lemeshow S. Applied logistic regression. 2nd ed. New York: Wiley; 2000

61. Hossain MG, Saw A, Mahumud RA, Ohtsuki F, Kamarul T. Multiple regression analysis of anthropometric measurements influencing the cephalic index of male Japanese university students. Singap Med J. 2013;54(9):516-20.

62. Seshan VE, Gönen M, Begg CB. Comparing ROC curves derived from regression models. Stat Med. 2013;32:1483-93.

63. Rutstein SRG. Guide to DHS statistics. In book quide to DHS statistics. ORC Macro: Calverton; 2012.

64. Morrell S, Perez DA, Hardy M, Cotter T, Bishop JF. Outcomes from a mass media campaign to promote cervical screening in NSW, Australia. J Epidemiol Community Health. 2010;64:777-83.

65. Juon HS, Kim M, Shankar S, Han W. Predictors of adherence to screening mammography among Korean American women. Prev Med. 2004;39(3):474-81.

66. Iqbal MS, Hossain MS, Niessen LW. Breast cancer in low-resource settings: prioritizing the awareness and access programmes to overcome sociocultural and economic barriers for early detection and improved outcomes. Eur J Cancer Prev. 2014;23(4):286-7.

67. Anderson JO, Mullins RM, Siahpush M, Spittal MJ, Wakefield M. Mass media campaign improves cervical screening across all socio-economic groups. Health Educ Res. 2009;24(5):867-75.

68. Mullins R, Wakefield M, Broun K. Encouraging the right women to attend for cervical cancer creening: results from a targeted television campaign in Victoria. Australia Health Educ Res. 2008;23(3):477-86.

69. Passalacqua R, Caminiti C, Salvagni S, Barni S, Beretta GD, Carlini P, Contu A, Di Costanzo F, Toscano L, Campione F. Effects of media information on 
cancer patients' opinions, feelings, decision-making process and physicianpatient communication. Cancer. 2004;100(5):1077-84.

70. Grilli R, Ramsay C, Minozzi S. Mass media interventions: effects on health services utilisation. Cochrane Database Syst Rev. 2002;1:CD000389.

71. Wakefield MA, Loken B, Hornik RC. Use of mass media campaigns to change health behaviour. Lancet. 2010;76:1261-71.

72. Bravi F, Decarli A, Russo AG. Risk factors for breast cancer in a cohort of mammographic screening program: a nested case-control study within the FRiCaM study. Cancer Medicine. 2018;7(5):2145-52.

73. Wee CC, McCarthy EP, Davis RB, Phillips RS. Obesity and breast cancer screening: the influence of race, illness burden, and other factors. J Gen Intern Med. 2004;19:324-31.

74. Hsia J, Kemper E, Kiefe C, Zapka J, Sofaer S, Pettinger M, Bowen D, Limacher $M$, Lillington $L$, et al. The importance of health insurance as a determinant of cancer screening: evidence from the women's health initiative. Prev Med. 2000;31(3):261-70.

75. Carrieri V, Wübker A. Assessing inequalities in preventive care use in Europe. Health Policy. 2013;113(3):247-57.

76. Goldzahl L, Hollard G, Jusot F. Increasing breast-cancer screening uptake: a randomized controlled experiment. J Health Econ. 2018;58:228-52.

77. Devaux M. Income-related inequalities and inequities in health care services utilisation in 18 selected OECD countries. Eur J Health Econ. 2015;16(1):2133.

78. Sicsic J, Franc C. Obstacles to the uptake of breast, cervical, and colorectal cancer screenings: what remains to be achieved by French national programmes? BMC Health Serv Res. 2014;14(465):1-13.

79. Wübker A. Explaining variations in breast cancer screening across European countries. Eur J Health Econ. 2014;15(5):497-514.

80. Jusot F, Or Z, Sirven N. Variations in preventive care utilisation in Europe. Eur J Ageing. 2012;9(1):15-25

81. Trivedi AN, Rakowski W, Ayania JZ. Effect of cost sharing on screening mammography in Medicare health plans. N Engl J Med. 2008;358(4):375-83.

82. Sözmen K, Unal B, Sakarya S, Dinc G, Yardim N, Keskinkilic B, Ergör G. Determinants of breast and cervical cancer screening uptake among women in Turkey. Asia Pacific J Public Health. 2016;28(6):528-38.

83. Dunn RA, Tan AK. Utilization of breast cancer screening methods in a developing nation: results from a nationally representative sample of Malaysian households. Breast J. 2011;17(4):399-402.

84. Menvielle G, Dugas J, Richard JB, Luce D. Socioeconomic and healthcare utilization-related determinants of cervical, breast and colorectal cancer screening practice in the French West Indies. Euro J Cancer Prev. 2018;27(3): 269-73.

85. Kisiangani J, Baliddawa J, Marinda P, Mabeya H, Choge JK, Adino EO, Khayeka-Wandabwa C. Determinants of breast cancer early detection for cues to expanded control and care: the lived experiences among women from Western Kenya. BMC Womens Health. 2018;18(81):1-9.

86. Topazian H, Cira M, Dawsey SM, Kibachio J, Kocholla L, Wangai M, Welch J, Williams MJ, Duncan K, Galassi A. Joining forces to overcome cancer: the Kenya cancer research and control stakeholder program. J Cancer Policy. 2016;7:36-41.

87. Vanderpuye V, Grover S, Hammad N, Simonds H, Olopade F, Stefan D. An update on the management of breast cancer in Africa. Infect Agents Cancer. 2017;12(1):13.

88. Unger-Saldaña K. Challenges to the early diagnosis and treatment of breast cancer in developing countries. World J Clin Oncol. 2014;5(3):465.

89. Kullgren JT, McLaughlin CG. Beyond affordability: the impact of nonfinancial barriers on access for uninsured adults in three diverse communities. J Community Health. 2010;35(3):240-8.

90. Kisuya J, Wachira J, Busakhala N, Naanyu V, Chite A, Omenge O, Otieno G, Keter A, Mwangi A, Inui T. Impact of an educational intervention on breast cancer knowledge in western Kenya. Health Educ Res. 2015;30(5):786-96.

91. Ginsburg OM, Chowdhury M, Wu W, Chowdhury MTI, Pal BC, et al. A health model to increase clinic attendance for breast symptoms in rural Bangladesh: can bridging the digital divide help close the cancer divide? Oncologist. 2014:19:177-85.

92. Tokosi TO, Fortuin J, Douglas TS. The impact of mHealth interventions on breast cancer awareness and screening: systematic review protocol. JMIR Res Protoc. 2017;6(12):e246.

93. Greenwald ZR, Fregnani JR, Longatto-Filho A, Watanabe A, Mattos JSC, Vazquez FL, Franco FL. The performance of mobile screening units in a breast cancer screening program in Brazil. Cancer Causes Control. 2018; 29(2):233-41.

\section{Publisher's Note}

Springer Nature remains neutral with regard to jurisdictional claims in published maps and institutional affiliations.

\section{Ready to submit your research? Choose BMC and benefit from:}

- fast, convenient online submission

- thorough peer review by experienced researchers in your field

- rapid publication on acceptance

- support for research data, including large and complex data types

- gold Open Access which fosters wider collaboration and increased citations

- maximum visibility for your research: over $100 \mathrm{M}$ website views per year

At BMC, research is always in progress.

Learn more biomedcentral.com/submissions 